\title{
FAKTOR-FAKTOR YANG BERHUBUNGAN DENGAN PEMENUHAN (KARBOHIDRAT DAN PROTEIN) DARI SARAPAN PAGI PADA SISWA KELAS III, IV DAN V DI SD NEGERI 54 BANDA ACEH
}

\author{
Factors That Are Related To Meeting (Carbohydrates And Proteins) From \\ Morning Breakfast On Classes Iii, Iv And V \\ At Sd Negeri 54 Banda Aceh \\ Ruri Widyasari*1, Darma Suri \\ Koresponding email : ruri@uui.ac.id ${ }^{* 1}$ \\ Universitas Ubudiyah Indonesia
}

\begin{abstract}
Abstrak
Melewatkan waktu sarapan berarti terjadi keterlambatan asuhan zat gizi (asupan gula kedalam sel darah) sehingga dapat menurunkan daya konsentrasi anak sewaktu belajar yang timbul karena rasa malas, lemas, lesu, pusing, serta menggantuk yang merupakan efek anemia pada anak. untuk mengetahui hubungan pendapatan keluarga, pengetahuan dan ketersediaan Sarapan dengan pemenuhan karbohidrat dan protein pada anak SDN 54 Banda Aceh. Bersifat deskriptif analitik dengan desain cross sectional. Pengambilan sampel menggunakan tehnik startified random sampling dengan jumlah 74 responden. Penelitian dilakukan pada tanggal 25 April sampai 16 Mei 2017 pada siswa kelas III, IV dan V di SDN 54 Banda Aceh. Cara pengumpulan data dengan membagikan kuesioner, selanjutnya dilakukan uji chi-square dengan tingkat kepercayaan $95 \%$ dan batas kemaknaan $(\alpha=0,05)$ Ha diterima $p$ value $<0,05$. bahwa dari 47 responden dengan pendapatan keluarga tinggi yang pemenuhan karbohidrat dari sarapan pagi kurang yaitu sebanyak 22 responden $(46,8 \%)$, dari 47 responden dengan pendapatan keluarga tinggi yang pemenuhan protein dari sarapan pagi kurang yaitu sebanyak 21 responden $(44,7 \%)$, dari 47 responden dengan pengetahuan cukup yang pemenuhan karbohidrat dari sarapan pagi kurang yaitu sebanyak 29 responden $(61,7 \%)$, dari 47 responden dengan pengetahuan cukup yang pemenuhan protein dari sarapan pagi kurang yaitu sebanyak 25 responden $(53,2 \%)$, dari 39 responden yang tidak tersedia sarapan pagi dengan pemenuhan karbohidrat dari sarapan pagi kurang yaitu sebanyak 32 responden $(82,1 \%)$ dan dari 39 responden yang tidak tersedia sarapan pagi dengan pemenuhan protein dari sarapan pagi kurang yaitu sebanyak 29 responden $(74,4 \%)$.Ada hubungan pendapatan keluarga dengan pemenuhan karbohidrat $(\mathrm{p}=0,003)$ dan protein $(\mathrm{p}=0,038)$ dari sarapan pagi, Ada hubungan pengetahuan dengan pemenuhan karbohidrat $(\mathrm{p}=0,001)$ dan protein $(\mathrm{p}=0,003)$ dari sarapan pagi, dan Ada hubungan ketersediaan sarapan dengan pemenuhan karbohidrat $(\mathrm{p}=0,000)$ dan protein $(\mathrm{p}=0,001)$ dari sarapan pagi pada siswa di SDN 54 Banda Aceh. Diharapkan gagi para siswa yang belum terbiasa sarapan pagi diharapkan lebih meningkatkan kebiasaan sarapan pagi untuk memenuhi derajat kesehatan dan status gizi yang optimal
\end{abstract}

\section{Kata kunci : pendapatan, pengetahuan, ketersediaan sarapan, karbohidrat, protein}

\begin{abstract}
Skipping breakfast means that there is a delay in nutrition care (intake of sugar into blood cells) so that it can reduce the child's concentration power when learning arises because of feeling lazy,
\end{abstract}


Journal of Healthcare Technology and Medicine Vol. 3 No. 1 April 2017

Universitas Ubudiyah Indonesia

e-ISSN : 2615-109X

weak, lethargic, dizzy, and sleepy which is the effect of anemia in children. to determine the relationship of family income, knowledge and availability of breakfast with the fulfillment of carbohydrates and protein in SDN 54 Banda Aceh children. Are descriptive analytic with cross sectional design. Sampling using startified random sampling technique with a number of 74 respondents. The study was conducted on April 25 to May 162017 in class III, IV and V students at SDN 54 Banda Aceh. Data collection methods by distributing questionnaires, then performed chi-square test with a confidence level of $95 \%$ and the significance limit $(\alpha=0.05)$ Ha accepted $p$ value $<0.05$. that from 47 respondents with high family income who fulfill carbohydrate from breakfast less, that is 22 respondents (46.8\%), from 47 respondents with high family income who fulfill protein from breakfast less that is 21 respondents (44.7\%), from 47 respondents with sufficient knowledge that carbohydrate fulfillment from breakfast was lacking as many as 29 respondents (61.7\%), from 47 respondents with sufficient knowledge that protein fulfillment from breakfast was lacking as many as 25 respondents (53.2\%), from 39 respondents who were not available for breakfast with carbohydrate fulfillment from breakfast were lacking as many as 32 respondents $(82.1 \%)$ and of 39 respondents who were not available for breakfast with protein fulfillment from breakfast lacking as many as 29 respondents (74.4\%) There is a relationship between family income and carbohydrate fulfillment $(p=0.003)$ and protein $(p=0.038)$ from breakfast. There is a relationship between knowledge and carbohydrate fulfillment $(p=0.001)$ and protein $(p=0.003)$ from breakfast, and There is a relationship between the availability of breakfast with the fulfillment of carbohydrates $(p=0,000)$ and protein $(p=0.001)$ from breakfast for students at SDN 54 Banda Aceh. It is hoped that the yeast of students who are not accustomed to having breakfast is expected to further enhance their breakfast habits to meet their optimal health and nutritional status

Keywords: income, knowledge, breakfast availability, carbohydrates, protein

\section{PENDAHULUAN}

Sarapan pagi merupakan suatu kegiatan makan dan minum yang penting sebelum melakukan aktivitas fisik. Sarapan pagi adalah menu pertama makan seseorang. Biasanya sarapan pagi dilakukan mulai dari bangun pagi sampai pukul 09.00 Wib. Sarapan pagi yang baik memenuhi 15 - $30 \%$ dari angka kebutuhan gizi harian dalam rangka mewujudkan hidup sehat, aktif dan cerdas (Hardinsyah \& Aries, 2012).

Sarapan penting bagi setiap orang untuk mengawali akitivitas sepanjang hari. Sarapan bertujuan untuk memenuhi kebutuhan zat gizi di pagi hari, sebagai bagian dari pemenuhan gizi seimbang, dan bermanfaat dalam membantu mencegah hipoglikemia, menstabilkan kadar glukosa darah, dan mencegah dehidrasi setelah berpuasa sepanjang malam (Gibson \& Gunn 2011).

Melewatkan waktu sarapan berarti terjadi keterlambatan asuhan zat gizi (asupan gula kedalam sel darah) sehingga dapat menurunkan daya konsentrasi anak sewaktu belajar yang 
Journal of Healthcare Technology and Medicine Vol. 3 No. 1 April 2017

Universitas Ubudiyah Indonesia

e-ISSN : 2615-109X

timbul karena rasa malas, lemas, lesu, pusing, serta menggantuk yang merupakan efek anemia pada anak.

Data juga menunjukkan akibat tidak sarapan pagi pada anak sebanyak 44,54\% anak indonesia tidak terpenuhi energinya,dan mengalami masalah Pentingnya ketersediaan pangan yang lengkap karena setiap jenis makanan memiliki kandungan gizi yang berbeda-beda. Perbedaan tersebut dapat berupa jenis zat gizi yang terkandung dalam makanan, maupun jumlah dari masing-masing zat gizi. zat gizi utama yang harus tersedia dalam sarapan pagi adalah karbohidrat dan protein yang dilakukan (Rampersaud et al., 2005).

Dalam menyusun menu sarapan, perlu diperhatikan kelengkapan gizi yang dikandungnya, terutama karbohidrat, protein, vitamin, dan mineral, (sayurdan buah) tinggi serat, dan rendah lemak (Rampersaud et al., 2005). Proporsi zat gizi makro anak sekolah yang dianjurkan sehari menurut pedoman umum gizi seimbang (PUGS) meliputi karbohidrat 50-60\%, lemak sekitar $25 \%$, dan protein sekitar $15 \%$, proporsi tersebut sudah mencakup sarapan pagi (Hermina et al., 2009).

Sarapan pagi penting bagi segala golongan umur karena melalui makan kita mempunyai energi untuk melakukan aktivitas hidup. Anak usia sekolah (SD), yang dikategorikan masih dalam taraf perkembangan dan pertumbuhan, maka makan pagi atau sarapan pagi mutlak sangat diperlukan untuk menunjang aktivitasnya, terutama di jam-jam belajar disekolah, energi yang diperlukan untuk belajar sangat bergantung dari asupan gizi yang diperoleh dari makanan yang dimakan. Apabila anak tidak sarapan maka energi yang dibutuhkan untuk berpikir tidak mendukung, dampaknya anak tidak konsentrasi untuk belajar karena perut kosong sehingga berpengaruh terhadap hasil belajarnya. (R.E.Kleinman,2013).

\section{METODE PENELITIAN}

Penelitian ini dilakukan melalui pendekatan observasional yang bersifat deskriptif analitik dengan menggunakan rancangan desain cross sectional dimana data variabel dependen dan data variable independen diambil dalam waktu yang sama.

Dalam penelitian ini peneliti ingin melihat Faktor-faktor yang berhubungan dengan pemenuhan asupan Energi, protein dengan kebiasaan sarapan pagi pada siswa di SD Negeri 54 Banda aceh. 
Journal of Healthcare Technology and Medicine Vol. 3 No. 1 April 2017

Universitas Ubudiyah Indonesia

e-ISSN : 2615-109X

Populasi adalah keseluruhan objek penelitian atau objek yang diteliti (Notoadmodjo, 2010). Populasi target penelitian ini adalah siswa yang duduk di bangku kelas III, VI dan V di SD NEGERI 54 Banda Aceh yang berjumlah 283 siswa.

Teknik pengambilan sampel dalam penelitian ini ada lah Startified Random sampling (Pengambilan sampel secara acak) yaitu sampel penelitian adalah seluruh siswa dari kelas III, IV dan kelas V yang berjumlah 283 siswa, yang terdiri dari kelas III terdiri 3 kelas. Kelas A Laki-laki sebanyak 14 siswa dan perempuan sebanyak 17 siswa total 31 siswa, Kelas B laki-laki sebanyak 16 siswa dan perempuan 14 siswa total 30 siswa, kelas C laki-laki sebanyak 16 siswa dan perempuan 17 siswa total 33 siswa, kelas IV terdiri 3 kelas. Kelas A laki-laki sebanyak 17 siswa dan perempuan 15 total 32 siswa, kelas B laki-laki sebanyak 18 siswa dan perempuan sebanyak 14 siswa total 32 siswa, kelas C laki-laki sebanyak 20 siswa dan perempuan sebanyak 13 total 33 siswa dan kelas V terdiri 3 kelas. Kelas A laki-laki sebanyak 17 siswa dan perempuan sebanyak 13 siswa total 30 siswa, kelas B laki-laki sebanyak 15 siswa dan perempuan sebanyak 16 siswa total 31 siswa, kelas C laki-laki sebanyak 13 siswa dan perempuan sebanyak 17 siswa total 30 siswa.

\section{HASIL DAN PEMBAHASAN}

A. Umur

Tabel 1

Distribusi Frekuensi Umur pada Siswa di SDN 54 Banda Aceh

\begin{tabular}{clcc}
\hline No & Umur & Frekuensi & $\%$ \\
\hline 1. & 9 Tahun & 24 & 32,4 \\
2. & 10 Tahun & 26 & 35,2 \\
3. & 11 Tahun & 24 & 32,4 \\
\hline & Total & 74 & 100 \\
\hline
\end{tabular}


Journal of Healthcare Technology and Medicine Vol. 3 No. 1 April 2017

Universitas Ubudiyah Indonesia

e-ISSN : 2615-109X

Berdasarkan Tabel 4.1 menunjukkan bahwa sebagian besar responden berumur 10 tahun yaitu sebanyak 26 responden $(35,2 \%)$.

B. Jenis Kelamin

Tabel 2

Distribusi Frekuensi Jenis Kelamin pada Siswa di SDN 54

Banda Aceh

\begin{tabular}{llcc}
\hline No & Jenis Kelamin & Frekuensi & $\%$ \\
\hline 1 & Laki-laki & 29 & 39,2 \\
2 & Perempuan & 45 & 60,8 \\
\hline & Total & 74 & 100 \\
\hline
\end{tabular}

Berdasarkan Tabel 4.2 menunjukkan bahwa sebagian besar responden berjenis kelamin perempuan yaitu sebanyak 45 responden $(60,8 \%)$.

C. Kelas

Tabel 3

Distribusi Frekuensi Jenis Kelamin pada Siswa di SDN 54 Banda Aceh

\begin{tabular}{clcc}
\hline No & Kelas & Frekuensi & $\%$ \\
\hline 1. & III & 24 & 32,4 \\
2. & IV & 26 & 35,2 \\
3. & V & 24 & 32,4 \\
\hline & Total & 74 & 100 \\
\hline
\end{tabular}

Berdasarkan Tabel 4.3 menunjukkan bahwa sebagian besar responden kelas IV yaitu sebanyak 26 responden $(35,2 \%)$.

Penelitian ini dilakukan di SDN 54 Kota Banda Aceh dengan jumlah responden 74 orang. Pengumpulan data dilakukan dengan cara membagikan kuesioner, maka diperoleh hasil sebagai berikut . 
Journal of Healthcare Technology and Medicine Vol. 3 No. 1 April 2017

Universitas Ubudiyah Indonesia

e-ISSN : 2615-109X

Karbohidrat

Tabel 4

Distribusi Frekuensi Karbohidrat pada Siswa di SDN 54 Banda Aceh

\begin{tabular}{llcc}
\hline No & Karbohidrat & frekuensi & $\%$ \\
\hline 1 & Kurang & 45 & 60,8 \\
2 & Cukup & 29 & 39,2 \\
\hline & Total & 74 & 100 \\
\hline
\end{tabular}

Berdasarkan Tabel 4.4 menunjukkan bahwa sebagian besar responden memperoleh asupan karbohidrat sarapan pagi pada kategori kurang yaitu sebanyak 45 responden $(60,8 \%)$.

Protein

Tabel 5

Distribusi Frekuensi Protein pada Siswa di SDN 54 Banda Aceh

\begin{tabular}{llcc}
\hline No & Protein & frekuensi & $\%$ \\
\hline 1 & Kurang & 40 & 54,1 \\
2 & Cukup & 34 & 45,9 \\
\hline & Total & 74 & 100 \\
\hline
\end{tabular}

Berdasarkan Tabel 4.5 menunjukkan bahwa sebagian besar responden memperoleh asupan protein sarapan pagi pada kategori kurang yaitu sebanyak 40 responden $(54,1 \%)$.

Pendapatan Keluarga

Tabel 6

Distribusi Frekuensi Pendapatan Keluarga pada Siswa di SDN 54 Banda Aceh

\begin{tabular}{llcc}
\hline No & Pendapatan Keluarga & frekuensi & $\%$ \\
\hline 1 & Rendah & 27 & 36,5 \\
2 & Tinggi & 47 & 63,5 \\
\hline & Total & 74 & 100 \\
\hline
\end{tabular}

Berdasarkan Tabel 4.6 menunjukkan bahwa sebagian besar pendapatan keluarga responden pada kategori tinggi yaitu sebanyak 47 responden $(63,5 \%)$.

Pengetahuan

Tabel 4.7

Distribusi Frekuensi Pengetahuan pada Siswa di SDN 54 Banda Aceh

\begin{tabular}{clcc}
\hline No & Pengetahuan & frekuensi & $\%$ \\
\hline 1. & Kurang & 13 & 17,6 \\
2. & Cukup & 47 & 63,5
\end{tabular}




\begin{tabular}{|c|c|c|}
\hline 3. Baik & 14 & 18,9 \\
\hline Total & 74 & 100 \\
\hline
\end{tabular}

Tabel 8

Distribusi Frekuensi Ketersediaan Sarapan pada Siswa di SDN 54 Banda Aceh

\begin{tabular}{llcc}
\hline No & Ketersediaan Sarapan & frekuensi & $\%$ \\
\hline 1 & Tidak Ada & 39 & 52,7 \\
2 & Ada & 35 & 47,3 \\
\hline & Total & 74 & 100 \\
\hline
\end{tabular}

Berdasarkan hasil pengamatan peneliti di lapangan, terdapat $44,7 \%$ orang tua dari siswa memiliki pendapatan tinggi, namun pemenuhan karbohidrat sarapan masih kurang. Jadi, terpenuhinya karbohidrat anak tidak hanya dipengaruhi oleh penghasilan orang tua saja namun juga dipengaruhi oleh sikap dan prilaku anak terhadap makanan. Dalam satu kondisi ibu tetap menyediakan sarapan pagi yang sesuai dengan gizi yang dibutuhkan anak, namun kebanyakan dari anak tersebut tidak mau makan dengan alasan, tidak lapar, tidak nafsu makan, telat bangun tidur, sehingga walaupun anak sarapan pagi, tetapi hanya sedikit sehingga tidak memenuhi jumlah kebutuhan karbohidrat sang anak. Anak lebih hanya memilih minum susu atau teh manis, tapi kurang berselera untuk makan makanan berat (mengandung karbohidrat) seperti nasi atau roti. Karena pada anak usia sekolah tidak mau makan atau tidak nafsu makan merupakan salah satu masalah yang sering ibu dapatkan.

Untuk memenuhi kebutuhan rumah tangga berhubungan dengan faktor yang paling menentukan kualitas dan kuantitas makanan.Terdapat hubungan yang erat antara pendapatan dan gizi yang di dorong oleh pengaruh yang menguntungkan dari pendapatan yang meningkat bagi perbaikan kesehatan dan masalah keluarga lainnya yang berkaitan dengan keadaan gizi. Tingginya tingkat pendapatan cenderung diikuti tingginya jumlah dan jenis pangan yang dikomsumsi. Tingkat pendapatan akan mencerminkan kemampuan untuk membeli bahan pangan (Noor, 2008).

Semakin tinggi pendapatan orang tua, maka akan semakin mudah dalam memenuhi kebutuhan karbohidrat sarapan pagi, karena dengan pendapatan yang tinggi ibu akan lebih mudah menentukan variasi menu sarapan. Misalnya, ibu tidak hanya menyediakan nasi pada saat sarapan sebagai sumber karbohidrat, namun ibu dapat 
Journal of Healthcare Technology and Medicine Vol. 3 No. 1 April 2017

Universitas Ubudiyah Indonesia

e-ISSN : 2615-109X

memvariasikan dengan roti, biskuit, kue/cake atau makanan olahan gandum lainnya serta dapat diselingi dengan bubur ayam. Begitu juga sebaliknya, dengan pendapatan yang rendah, ibu akan mengalami kesulitan dalam memvariasikan menu sarapan, sehingga anak akan mudah mengalami kebosanan dan pada akhirnya anak tidak mau makan (Khomsan, 2010).

Sejalan dengan penelitian yang dilakukan oleh Febrianto (2012) mengemukakan bahwa adanya hubungan positif yang signifikan antara tingkat penghasilan orangtua dengan pemenuhan gizi sarapan pagi anak sekolah dasar di Desa Karang Ampel Indramayu, dengan nilai korelasi sebesar 0,649, maka orangtua yang memiliki tingkat penghasilan yang mapan dari segi penghasilan akan memperhatikan kualitas asupan gizi anaknya, setiap kali memberi makanan akan mempertimbangkan yang terbaik yang dapat menunjang pertumbuhan bagi anaknya. Orangtua yang memiliki penghasilan yang rendah biasanya memberi asupan makanan seadanya tanpa mempertimbangkan kualitas gizi yang baik bagi tumbuh kembang anaknya.

\section{KESIMPULAN}

Setelah dilakukan penelitian dan uji statistik tentang faktor-faktor yang berhubungan dengan pemenuhan gizi (karbohidrat dan protein) dari sarapan pagi pada siswa di SDN 54 Banda Aceh, bahwa:

1. Ada hubungan pendapatan keluarga dengan pemenuhan karbohidrat dari sarapan pagi pada siswa di SDN 54 Banda Aceh ( $p$ value =0,003).

2. Ada hubungan pendapatan keluarga dengan pemenuhan protein dari sarapan pagi pada siswa di SDN 54 Banda Aceh ( $p$ value = 0,038).

3. Ada hubungan pengetahuan dengan pemenuhan karbohidrat dari sarapan pagi pada siswa di SDN 54 Banda Aceh ( $p$ value = 0,003).

4. Ada hubungan pengetahuan dengan pemenuhan protein dari sarapan pagi pada siswa di SDN 54 Banda Aceh ( $p$ value = 0,001).

5. Ada hubungan ketersediaan sarapan dengan pemenuhan karbohidrat dari sarapan pagi pada siswa di SDN 54 Banda Aceh ( $p$ value $=0,000$ ).

6. Ada hubungan ketersediaan sarapan dengan pemenuhan protein dari sarapan pagi pada 
Journal of Healthcare Technology and Medicine Vol. 3 No. 1 April 2017

Universitas Ubudiyah Indonesia

e-ISSN : 2615-109X

siswa di SDN 54 Banda Aceh ( $p$ value = 0,001).

\section{DAFTAR PUSTAKA}

Aghadiati, faradina. 2015. Hubungan pengetahuan ibu dengan pola menu sarapan dan kebiasaan sarapan pada anak sekolah dasar di SD muhammadiyah karangkajen Yogyakarta. Universitas gajah mada.

Almatsier, S., soetardjo, S. \& soekarti, M.2011. gizi seimbang dalam daur kehidupan, Jakarta, PT gramedia pustaka utama.

Fitri CN. 2012. Faktor-Faktor Yang Berpengaruh Dengan Kebiasaan Konsumsi Makanan Jajanan Pada Siswa Sekolah Dasar Di SDN Rawamangun 01 Pagi Jakarta Timur Tahun 2012. Jakarta:Universitas Indonesia.

Hastuti. 2012. Hubungan Asupan Energi Protein, Lemak, dan Karbohidrat dengan Status Gizi Anak Pada Anak Usia Sekolah di Kelurahan Sangkrah dan Semanggi Kecamatan Pasar Kliwon Kota Surakarta. Thesis. Univ Muhammadiyah Surakarta

Hastono, S. P. 2006. Basic Data Analysis for Health Research. Universitas Indonesia (UI) : Fakultas Kesehatan Masyarakat.

Hermina, Ari Nofitasari \& Anggorodi, R., 2009. Faktor-Faktor Yang MemengaruhiKebiasaan Makan Pagi Pada Remaja Putri Di Sekolah Menengah Pertama(Smp).

Kumala S. 2013. Faktor Determinan Terhadap Kebiasaan Sarapan Siswa Di Smp itinsan harapan tanggerang selatan [Thesis].Depok : Universitas Indonesia.

Kusprasetetia maudi tini, 2016. Hubungan antara kebiasaan sarapan dengan status gizi dan prestasi belajar pada anak sekolah dasar di kota bogor. Institut pertanian bogor

Mariza, Yuni Y. 2012. Hubungan antara kebiasaan sarapan dan kebiasaan jajan dengan status gizi anak sekolah dasar di kecamatan pendurungan kota semarang . Universitas Diponegoro, Semarang.

Meriska (2013) Perilaku Sarapan Pagi Anak Sekolah Dasar .Jurnal Gizi Dan Pangan Millimet $D L$, Tchernis $R$, Husain M. (ed) 2010. School nutrition programs and theincidence of childhood obesity.Journal of Human Resources.

Murphy JM. (ed.). 2007. Breakfast and learning: an updated review. Current Nutrition \& Food Science.

Notoatmodjo S. 2010. Meteodologi Penelitian Kesehatan ,Rineka Cipta.Jakarta 
Journal of Healthcare Technology and Medicine Vol. 3 No. 1 April 2017

Universitas Ubudiyah Indonesia

e-ISSN : 2615-109X 
Journal of Healthcare Technology and Medicine Vol. 3 No. 1 April 2017

Universitas Ubudiyah Indonesia

e-ISSN : 2615-109X 
Journal of Healthcare Technology and Medicine Vol. 3 No. 1 April 2017

Universitas Ubudiyah Indonesia

e-ISSN : 2615-109X

Berdasarkan Tabel 4.8 menunjukkan bahwa sebagian

besar responden tidak tersedia sarapan yaitu sebanyak 49

responden $(52,7 \%)$. 
Journal of Healthcare Technology and Medicine Vol. 3 No. 1 April 2017

Universitas Ubudiyah Indonesia

e-ISSN : 2615-109X 